\title{
Jubileusz prof. dr hab. Józefa Miąso. Seminarium Atlas historyczny szkót na ziemiach polskich: Problemy sieci szkolnej Okregu Naukowego Wileńskiego Pultusk 3-4.06.2004 r.
}

W dniu 3 czerwca 2004 r. w Pułtusku miał miejsce Jubileusz prof. dr hab. Józefa Miąso, na który przybyły delegacje historyków oświaty reprezentujace ośrodki naukowo-badawcze z całej Polski. Rektor Wyższej Szkoły Humanistycznej im. Aleksandra Gieysztora prof. dr hab. Adam Koseski witając zgromadzonych gości wyraził radość z możliwości zorganizowania tej uroczystości w murach uczelni w Pułtusku. Stwierdził, iż Szkoła swój sukces zawdzięcza profesorom tej rangi jak prof. dr hab. Józef Miąso.

Uroczysta laudację wygłosił prof. dr hab. Julian Dybiec. Zaprezentował dorobek naukowy i wkład Jubilata do rozwoju historii wychowania i pedagogiki porównawczej, szczególnie w zakresie zagadnień historiografii, historii zawodu nauczycielskiego, myśli pedagogicznej oraz reform oświaty polskiej na tle tendencji międzynarodowych.

Profesor J. Dybiec podkreślił wartość warsztatu naukowo-badawczego Jubilata, zdumiewająca dyscyplinę naukowa, skrupulatność w gromadzeniu i opracowaniu źródeł oraz precyzję metodologiczna. W konkluzji znakomitej laudacji prof. dr hab. J. Dybiec stwierdzil, że cechy osobowości Profesora pozwalają na uznanie go za wzorzec $w$ dziedzinie nauk historycznych porównywalny do wzorca Sevres pod Paryżem.

Z kolei prof. dr hab. Irena Szybiak i prof. dr hab. Kalina Bartnicka przedstawily dostojnego Jubilata jako uczonego, mistrza, przyjaciela i kolegę.

Następnie delegacje wygłosiły okolicznościowe przemówienia, złożyły gratulacje i wręczyły kwiaty. Profesor J. Miasso podziękował wszystkim przybyłym na Jubileusz przyjaciołom, kolegom i koleżankom. Szczególne wyrazy wdzięczności skierował do żony, która wspierała go w pracy i w życiu. W krótkim rysie autobiograficznym zwrócił uwagę na przełomowe momenty w swoim życiu, które zadecydowały o zainteresowaniach, pracy naukowej oraz sukcesie osobistym i zawodowym.

Punktem kulminacyjnym było wręczenie księgi pamiątkowej dedykowanej Jubilatowi pt.: Historia. Społeczeństwo. Wychowanie ${ }^{1}$ przez Profesorów: Kalinę Bartnicka i Irenę Szybiak. Praca obejmuje artykuły i rozprawy podzielone na cztery grupy problemowe: tradycja uniwersytecka, stan nauczycielski, szkoły i nauczanie, edukacja a społeczeństwo. 100 lat.

Na zakończenie uroczystości prof. zw. dr hab. Lech Mokrzecki zaintonował wspólne, uroczyste

Obchody Jubileuszu prof. dr hab. Józefa Miąso połączone były z seminarium naukowym Atlas historyczny szkót na ziemiach polskich. Obrady poświęcono problemom sieci szkolnej Okręgu Naukowego Wileńskiego. Zagadnienia szkolnictwa parafialnego analizowali dr Adam Fijałkowski (Szkoły parafialne na Litwie przed powstaniem Komisji Edukacji Narodowej), dr Katarzyna Buczek (Koncepcja szkolnictwa parafialnego Hugona Kołlataja w poczatku XIX w.) oraz doc. dr hab. Leszek Zasztowt (Szkoły elementarne na ziemiach litewsko-ruskich po roku 1832).

Z kolei problematykę szkół średnich i wyższych podjęli: prof. dr hab. Kalina Bartnicka (Komitet Szkolny Uniwersytetu Wileńskiego), dr Joanna Schiller (Absolwenci Uniwersytetu Wileńskiego

\footnotetext{
${ }^{1}$ Historia. Spoleczeństwo. Wychowanie. Ksiega pamiątkowa dedykowana Profesorowi Józefowi Miąso, pod red. Kaliny Bartnickiej przy współpracy Joanny Schiller i zespołu pracowników Zakładu Dziejów Oświaty Instytutu Historii Nauki Polskiej Akademii Nauk oraz Katedry Historii Wychowania Wydziału Pedagogicznego Wyższej Szkoły Humanistycznej im. Aleksandra Gieysztora w Pułtusku: Tadeusza Bieńkowskiego, Katarzyny Buczek, Janiny Chodakow skiej, Katarzyny Dormus, Adama Fijałkowskiego, Wandy Gierlach, Janiny Kamińskiej, Jana Piskurewicza, Wojciecha Sokolowskiego, Ireny Szybiak, Ryszarda Terleckiego, Eweliny Tylińskiej, Leszka Zasztowta, Wyższa Szkoła Humanistyczna im. Aleksandra Gieysztora w Pultusku, Pultusk-Warszawa 2004.
} 
- nauczyciele szkół średnich w Królestwie Polskim), doc. dr hab. Jan Piskurewicz (Organizacja Uniwersytetu Stefana Batorego po I wojnie światowej), dr Katarzyna Dormus (Kraków-Wilno: organizacja Wydziału Sztuk Pięknych Uniwersytetu Stefana Batorego w Wilnie), dr Janina Kamińska (Sieć szkół średnich na Litwie w latach 1795-1803 a Szkoła Główna Litewska), dr Janina Chodakowska (Szkoła krzemieniecka w sieci szkolnej WON) i mgr Wanda Gierlach (Głosy w sprawie pensji żeńskich w Okręgu Szkolnym Wileńskim).

Prof. dr hab. Irena Szybiak w swoim wystapieniu zwróciła uwagę na politykę Komisji Edukacji Narodowej w kwestii sieci szkolnej, a doc. dr hab. Wanda Grębecka omówiła założenia dydaktyczne ogrodów botanicznych w Okręgu Naukowym Wileńskim. Mgr Ewa Wołoszyn przedstawiła współpracę drukarni Józefa Zawadzkiego z Uniwersytetem Wileńskim.

Obradom towarzyszyły ożywione dyskusje. W wystapieniach poruszano problemy: zasobów bibliotek wileńskich (doc. dr hab. Leszek Zasztowt, dr Janina Kamińska, dr Dorota Zamojska, doc. dr hab. Jan Piskurewicz), atrakcyjności Wilna jako ośrodka naukowego w czasach zaborów i w Drugiej Rzeczypospolitej, a także licznych błędów merytorycznych w polskim przekładzie dzieła Daniela Beauvois $^{2}$ (prof. Wołoszyński). Postulowano prowadzenie dalszych badań porównawczych w zakresie: organizacji litewskiego szkolnictwa parafialnego i protestanckich szkół pomorskich (prof. zw. dr hab. Lech Mokrzecki), działalności Komitetów Szkolnych (prof. dr hab. Kalina Bartnicka), pensji żeńskich (prof. dr hab. Piotr Gach) oraz podręczników, programów i sieci szkolnej. Podnoszono kwestię konieczności ponawiania prób uzyskania dostępu do zbiorów źródel archiwalnych poza granicami Polski.

Zamykając ostatnią sesję obrad prof. zw. dr hab. Lech Mokrzecki dziękując organizatorom Jubileuszu i seminarium: JM Rektorowi WSH w Pułtusku oraz Profesorom Irenie Szybiak i Kalinie Bartnickiej stwierdzil, że jest to jedna z najlepszych konferencji w ostatnich latach krystalizująca badania nad szkolnictwem Okręgu Naukowego Wileńskiego.

Prof. dr hab. Irena Szybiak poinformowała o uruchomieniu stałej strony internetowej i pracach Towarzystwa Historii Edukacji. Duże zainteresowanie wzbudziły przedstawione przez prof. dr hab. Krzysztofa Jakubiaka nowe standardy edukacyjne ograniczające liczbe godzin przeznaczonych na realizacje przedmiotu historia wychowania. Ocenione zostały jednoznacznie przez uczestników seminarium jako cios $w$ kulturę kształcenia pedagogów i brak zrozumienia idei przedmiotów kierunkowych w edukacji nauczycielskiej.

W trakcie seminarium prof. dr hab. Irena Szybiak i prof. dr hab. Kalina Bartnicka ogłosiły nazwiska laureatów ogólnopolskiego Konkursu Prac Magisterskich z Historii Edukacji o Nagrodę im. Profesora Czesława Majorka.

Ewelina Tylińska otrzymała dyplom nr 1 i nagrodę pierwszego stopnia za pracę magisterską poświęcona studentom Cesarskiego Uniwersytetu w Warszawie w latach $1869-1904$ jako grupie akademickiej $\mathrm{i}$ ich znaczeniu w życiu miasta. Praca została napisana pod kierunkiem naukowym prof. dr hab. Kaliny Bartnickiej, a recenzentami byli: prof. dr hab. Julian Dybiec i doc. dr hab. Leszek Zasztowt.

Z kolei I Nagroda im. Profesora Czesława Majorka w drugiej edycji Konkursu została przyznana Monice Nawrót za prace nt.: Rola rodziny i nauczania domowego w utrzymaniu tożsamości narodowej Polaków na terenie zaboru rosyjskiego $w$ drugiej polowie XIX wieku $i$ w poczatkach wieku XX $w$ świetle pamiętnikarstwa. Praca została napisana pod kierunkiem naukowym prof. dr hab. Krzysztofa Jakubiaka.

\section{Ewa Romanowska Joanna Dabrowska}

\footnotetext{
${ }^{2}$ Daniel Beauvois, Szkolnictwo polskie na ziemiach litewsko-ruskich 1803 - 1832. Uniwersytet Wileński, przeł. z jęz. francuskiego Ireneusz Kania, t. 1, Fundacja Jana Pawła II $\rightarrow$ Rzym, Redakcja Wydawnictw KUL, Lublin 1991. Daniel Beauvois, Szkolnictwo polskie na ziemiach litewsko-ruskich 1803-1832. Szkoły podstawowe i średnie, przeł. z jęz. francuskiego Ireneusz Kania, t. 2, Fundacja Jana Pawla Il - Rzym, Redakcja Wydawnictw KUL, Lublin 1991.
} 